European Journal of Business and Innovation Research

Vol.9, No.2, pp. 12-26, 2021

Print ISSN: 2053-4019(Print),

Online ISSN: 2053-4027(Online)

\title{
IMPACT OF CORONAVIRUS DISEASE (COVID-19) ON BUSINESS IN EDO STATE, NIGERIA
}

\author{
Owenvbiugie, Robinson Osarumwense \\ University of Benin. Nigeria \\ Vocational and Technical Education \\ Education Faculty \\ E-mail: osarumwense.owenvbiugie@ uniben.edu
}

\begin{abstract}
The study assessed the impact of COVID-19 on business in Nigeria. Four research questions gave focus to the study. 234 respondents were used using an accidental sampling technique. A descriptive survey gave credence to the study. A reliability coefficient of 0.79 was obtained with the use of Cronbach alpha formula. Data was obtained with the aid of questionnaire. Research questions were answered with mean. From the result, it was discovered that COVID-19 impacted profit, sales volume and business cash flow. The study concluded that COVID-19 has impact on profit, sales volume and cash flow of business. It was also concluded business derived a lot of benefits from COVID-19 pandemic. Consequently, it was recommended that business owners should engage in market timing to enable their customers to know their time of opening, engage more in online sales to increase sales volume, as well engage in massive savings to avoid cash crunch during economic crises.
\end{abstract}

KEY WORDS: COVID-19; business; profit margin; sales volume, cash flow JEL Classification: M5, M21

\section{INTRODUCTION}

Business appears to be the main stay of any economy throughout the world. This is why Hayes (2019) sees business as an enterprise concerned with activities aimed at improving the lives of people in a given locality. Businesses may be a profit or non-profit depending on the aim of such businesses. From the foregoing business is deemed to be responsible for overall development of a nation's economy be it communist, or democratic governance without which activities of these nations will collapse. For business to stay afloat, it has to make profit to enable it to grow and expand. Profit may be seen as the amount of income a business generates over a given time frame. This could be gross profit or net profit. This is why Johnson (2019) stressed that business must make profit when she is able to borrow money, attract investors' financing as well as hire more employees. Making profit in a business is an important ingredient that will encourage expansion of business vis-a vis opening other branches within and outside its location, targeting larger markets. Business profit may encourage foreign investors. Emphasizing the importance of profit, York (2019) opined that for business to make profit, it must change its mode of operation, and reduce costs at all levels of business operations. York further maintained that business owners should maximize cash flow, raise market bar, staying visibly connected, streamlining management costs, and making everybody sales representatives. For a profit of a business to increase, there must be increase in sales. Accounting Tools (2020) sees sales volume as the unit number of goods sold over a time frame. This why, Kokemuller (2020) stated that sales volumes are used to measure 
European Journal of Business and Innovation Research

Vol.9, No.2, pp. 12-26, 2021

Print ISSN: 2053-4019(Print),

Online ISSN: 2053-4027(Online)

the performance of employees. It aids business owners in determining incentives and bonuses to be given to workers for their commitments to organizational goals. Cash determines the solvency of a business. Corporate Finance Institute (2020) defined cash flow as the amount of money available to a business. Cash flow seems to represent revenue growth, operating margin as well as capital efficiency of a business. It is used to describe the availability of cash that is generated or consumed over a period of time. However, a number of benefits seem to be achievable during the period of COVID-19, this according to Davies (2020) include increase in cloud computing, video conferencing, electronic payments, e-learning, among others. A number of factors may bring about the collapse of business such as health reasons, market timing, regulatory issues, fund crunch, reactive attitude, underpricing of goods and services, over reliance on one customer, cash flow difficulties, and unforeseen events such as viruses. Virus in any form has done a lot of damage both to human lives as well as businesses.

Virus is any organism that has the tendency to flourish in and outside of its host. Viruses have been ravaging the world to a very high magnitude from 1950 to 2019. The known ones according to Harding (2020) include Marburg virus of 1967; the Spanish flu of 1918 that claimed the lives of over 50 million people; Dengue virus of 1950 which started in Philippines and Thailand; Smallpox of 1980 virus which claimed the lives of over 300 million people; HIV of 1980 that claimed the lives of 32 million people; Hantavirus of 1993; SARs-CoV of 2002 which was first noticed in China that killed 770 people within two years; Rotavirus of 2008 that claimed the lives of 453,000 children; Swine-flu pandemic of 2009 that claimed the lives of 203,000 across the globe; MERS-CoV of 2012 found in Saudi Arabia and 2015 in South Korea; and SARS-CoV-2 popularly known as Coronavirus. The most recent virus that is ravaging the world is Coronavirus also known as COVID-19. This virus is purported to have originated in China in 2019 that has claimed many lives. Shereen, Khan, Kazmi, Bashir, and Siddique (2020) reported that it has affected 2,724,809 confirmed cases and 187847 deaths in 213 countries across the globe. In Nigeria it was 1532 reported cases with 44 deaths as at $29^{\text {th }}$ April 2020 . Here in Edo State the number of confirmed cases was recorded as 29 and 4 deaths. European Centre for Diseases Prevention and Control (2020) reported as at 31 ${ }^{\text {st }}$ May reported that Africa had 141,632 confirmed cases with 4071 deaths; Asia had 1095786 confirmed cases with 30065 deaths; America had 2846391 confirmed cases with 161514 deaths; Europe had 1934991 confirmed cases with 173155 deaths; Oceania recorded 8639 cases with 132 deaths; and others put at 696 cases, while the world deaths has been put at 368,944, 847. Here in Edo State the number of confirmed cases is recorded as 284 confirmed cases with13 deaths. With this ongoing trend, COVID-19 may reduce profitability of business; sales volume, and cash flow, among others. Profit is the surplus of income over expenses over a given period. Sales volume is the pieces of items sold in a given period, while cash flow is the currency at which cash that is generated and used over a period of time. The COVID-19 has put many businesses in a precarious situation that is making them to panic thereby making some adjustments in their financial commitments to employees and business expansion. Due to COVID-19 pandemic, there has been threat to lives and businesses, while various governments across the world have put up measures in place to curb the spread. In many countries there have been total locks down of all economic activities, Nigeria is not an exception. Nigeria has closed all businesses, be it big or small with the aim of curbing the spread. In Edo State for example, all businesses including small business owners have been forced to close. Artisans, 
European Journal of Business and Innovation Research

Vol.9, No.2, pp. 12-26, 2021

Print ISSN: 2053-4019(Print),

Online ISSN: 2053-4027(Online)

mechanics workshops, spare parts dealers, sellers of goods and services, civil servants have been temporarily put on hold. The only sellers of goods and services that are left in this total lock down are those selling food stuffs as well as pharmaceutical stores.

As a result of Coronavirus ravaging the world, many businesses, both small and large including limited liability companies are downsizing in order to cut cost, some are at the verge of closing down, while others have shut-up. Ibekwe (2020) reported that Arik Air, Nigeria biggest commercial Airline had informed the world that it would cut the salaries of its workers by about 80 per cent, and that 90 per cent of its staffers may be laid off without pay from May 1. 2020 if COVID-19 remains unabated. Many organizations in recent times in public and private sectors as well as petty traders are threatening to close up their businesses; some are threatening to down size their workforce, while some still are threatening to slash salaries of their workers. What could be responsible for these threats is not immediately known. Could it be the ravaging COVID-19 virus? If this is allowed to continue unchecked the entire world may be thrown into recession that may spell disaster for mankind.

\section{LITERATURE REVIEW}

\section{Economic Impact of Covid-19}

There has been apprehension across the globe of the ravaging impact of COVID-19 on businesses. It appears that this apprehension is coming to fruition as no solution is in sight. A lot of businesses are crumbling. This is why $\mathrm{Ng}$ (2020) stated that impact of Covid-19 would be felt in the capital markets; tourist's industry may go into extinction as result of ban on flights and lockdowns. $\mathrm{Ng}$ further said that as a result of ban on flights, Chinese customers have suspended demanding new purchases. Given this scenario, Dubai flourishing economy may experience glut of goods where supply will be higher than demand. $\mathrm{Ng}$ (2020) further opined that with Covid-19, the United Arab Emirate cancelled its Expo 2020, and Saudi Arabia did not allow the annual haj pilgrimage to be performed which has been a source of revenue amounting to millions of dollars on a yearly basis. Oil prices summersaulted with the flooding of the market by Riyadh, causing great harm in oil prices. In the same vein, Bianco (2020) stated that Egypt will be losing a whopping sum of US\$1 billion revenue per month in tourism sub-sector. $\mathrm{Ng}$ (2020) concluded that the economic impact of Covid-19 will go a long way in having negative impact as the oil price may go down as demand will be to its low ebb. Riboua (2020) opined that as a result of the Covid-19 pandemic, Lebanon has defaulted in a US $\$ 1.2$ billion Eurobond payment. This situation has prevented it from funding ailing health infrastructure as well as preventing it from importing medical supplies. Abioye (2020) stressed that COVID-19 pandemic that is ravaging the world especially in the health sub-sector has made the health workers immobile, as well as many workers in the health sector losing their lives daily to this virus that has defied seemingly all solutions despite all efforts made by all and sundry. Abioye further stated that with battling with Covid-19 across the globe, emphasis may be shifted to funding the health sector depriving other sectors from receiving attention. This, in the long run may reduce food production, which will invariably make demand exceed supply making food price to increase. This will cause untold hardship to many inhabitants who cannot afford their daily meals. Abioye concluded that as a result of Covid-19, Nigeria is considering the reduction of its budgetary allocation in all sectors as a result of drop in oil prices to 20 dollars per barrel as 
European Journal of Business and Innovation Research

Vol.9, No.2, pp. 12-26, 2021

Print ISSN: 2053-4019(Print),

Online ISSN: 2053-4027(Online)

against the budgeted provision of 57 dollars per barrel. This may in turn affect the monthly allocation to states and local governments in the country. This may also affect payment of salaries to workers. This may have a ripple effect as farmers may not be able to produce because of low patronage as a result of low purchasing power of the people. In another development, Ozili and Arun (2020) maintained that the Covid-19 is affecting the world's economy through social distancing which has invariably led to the shutdown of financial institutions, businesses and events, and moreover, shutdown of investment among stakeholders. The researchers argued that the pandemic may trigger the world into recession. Akanni (2020) opined that with Covid-19, global economy has badly affected the Nigerian economy through reduction in oil exploration. This reduction in oil demand may plunge Nigerian economy into recession. As a result of the ban on global travel, spending by people may continue to decline. Hotels and hospitality are also hard up facing tremendous demand and patronage. Akanni further reported that in Hungary, about 40 to $50 \%$ of hotel reservations have been put on hold. Also, the Covid-19 pandemic is putting at risk a great loss of jobs in leisure and hospitality sub-sector. About 80 million people may lose their jobs in United States of America as a result of flights cancellations. The closure of private educational institutions and schools in Nigeria is having untold hardship on its owners. The researcher queried if this continues unabated many of these institutions may stop the salary of these workers on their payroll. This may have adverse effects on parents who have other needs to cater for. Onyekwena and Ekeruche (2020) stated that prior to Covid-19 pandemic; the Nigerian government had been battling with recession occasioned by drop in the price of oil in 2014. This drop in oil price reduced the country's GDP growth rate to 2.3 percent in 2019. The growth rate further dropped to 2 percent, as a result of drop in oil prices. As a result of this decline, the debt profile soared to a ratio of 60 percent. The researchers maintained that with Covid-19, the debt profile may likely worsen as a result of declining revenue occasioned by falling oil prices. The researchers further stressed that there will be aggregate demand, while government expenditure will rise. This made government increased its budgetary allocation from 8.83 trillion naira in 2019 to 10.59 trillion naira in 2020 . As a result of Covid-19, there is a fall in household consumption in Nigeria as a result of imposition of a lockdown in the entire country. The informal sector contributes a large proportion of its revenue to government coffer. As a result of the Covid-19 pandemic, investments by firms may be greatly affected. It has led to decline in stock prices. This has further increased government purchases to counteract the fall in consumer spending. It may also lead to a fall in global demand for goods and services. This is occasioned by the restrictions on movement of people and border closures. Chilufa (2020) maintained that the Coronavirus (COVID-19) has affected supply chain disruptions due to port closures in China. This has caused multiplier effects as most Africa businesses are in the informal sector which depends solely on goods manufactured in China and shipped to Africa. As a result of the pandemic there has been a resultant decrease in demand by Africans. Importers in China are putting on hold orders due to port closures. In Africa, the virus's global impact is in turn directly affecting local economies as small business depend on goods imported from China and resold to other users. Chilufa further said that no other country in Africa consumes more Chinese products than Nigeria. As a result of border closures many business people have cancelled overseas trips, thereby putting on hold goods manufactured in China. This has greatly affected these businesses to close up. 
European Journal of Business and Innovation Research

Vol.9, No.2, pp. 12-26, 2021

Print ISSN: 2053-4019(Print),

Online ISSN: 2053-4027(Online)

\section{Covid-19 and Profit Margin of Business}

Egba (2020) reported that MTN Nigeria recorded a significant increase in its revenue from 282.1 billion Naira to 329.1 billion Naira in the first quarter of 2020. Egba maintained that MTN Telecommunication Company has made a steady growth during the pandemic period owing to the enforced lockdown. Egba further stated that the company made a profit of $\$ 51.1$ billion in the first quarter of 2020 compared to $\$ 48.4$ billion in the first quarter of 2019. Egba concluded that MTNN's share price tumbled to as low as N90 in March 2020. Switzerland (2020) reported a negative growth, as well as decline in sales. Switzerland concluded that E-commerce sales reached $29.4 \%$ which exceeded $10 \%$ of total Group sales before Covid-19. Seen (2020) opined that during this time of COVID-19 crisis, businesses incur operating losses. Seen further maintained that during lockdown virtual meetings are held making it at times to be practically impossible to sign some agreed documents on line, while some documents may not be visible for signature. Covid19 also affects the stock markets and financial markets as a result of gloomy forecasts and cash flow pressures. Kim (2020) reported that the Consumer Electronics Division recorded lower earnings as a result of COVID-19 compared to a year before as well as decline in sales from TV business. Coonrod (2020) stressed that distiller of Missouri Ridge Distillery maximized an increase of profit in the production of hand sanitizer during covid-19 pandemic. In the same vein, Kilpatrick, Dess, and Barter (2020) maintained that tourism, hospitality, entertainment and air transportation had felt the negative impact of Covid-19 in the short run, but, businesses in consumer goods and retail may also face higher financial risk more especially those having their supplies from China. Commenting on profit margin during Covid-19 pandemic, Singh (2020) reported that Puma's sales declined in the first quarter of 2020 due to impact of Corona virus that is ravaging the global market

\section{Covid-19 and Sales Volume}

The impact of Covid-19 is affecting sales volume of many businesses. This is why White (2020) reported that Coca-Cola company global sales volumes fell by $25 \%$ in the first quarter of 2020. White further stated that the company had a short fall in its sales to $\$ 8.6$ billion, representing a fall of 1\% compared to the same period a year before. Influencer Marketing Hub (2020) opined that YouTube videos watchers in Italy increased 20 times growth considerably compared to same period in 2019. Aman (2020) stated that the auto sector has been badly affected by Covid-19 resulting from the sales of vehicle dropping to 683,000 units. Aman further stated that the sales of vehicles dropped to 197,000 units of vehicles compared to 328,000 units in 2019. Shaulova (2020) revealed that during the coronavirus in Italy, the sales of over-the-counter in healthcare items increased significantly. Sales volume of pharmaceutical products grew by 30 percent compared to the same period of the previous year. Meyer (2020) stated that sales volume of apparel dropped to as low as $20 \%$.

\section{Covid-19 and Cash Flow}

It appears that cash flow is the life blood of any business be it privately owned or a limited liability company. ACCA Canada (2020) reported that Covid-19 has negatively affected employees' productivity by $52 \%$, launch of new products or services by $27 \%$ and cash flow stood at $23 \%$. In the same vein, Foss (2020) stated that as a result of the coronavirus, business owners are 
European Journal of Business and Innovation Research

Vol.9, No.2, pp. 12-26, 2021

Print ISSN: 2053-4019(Print),

Online ISSN: 2053-4027(Online)

experiencing tight cash flow to run various arms of their business. To complement Foss, Shah (2020) maintained that the major problem confronting business in this Covid-19 pandemic is the issue of cash flow which has been a hindrance to many organizations. Shah, further stated that many businesses are restructuring their operations to enhance their cash flows. To overcome the uncertainties of cash flow, Tregurtha (2020) identified the following to overcome cash flow difficulty and business uncertainties, organizations should provide business services virtually as result of social distancing as well as lockdown restrictions to control the virus spread which is capable of ruining small business cash flow. The business needs to offer pick-up delivery service, e-commerce site or online delivery platform maybe opened because of restrictions on movements. Business owners should stay in close contact with their customers through email and social media platform. To overcome cash flow difficulty, business owners should closely work with their vendors and suppliers to avoid cash crunch. Suppliers who are credit worthy can supply goods on credit basis. Business owners should also look for financial help from either state, local, and federal authorities.

\section{Possible Advantages of Covid-19 on Business}

Covid-19 may have dealt a big blow to organizations. Some have completely shut down, some doing skeletal services, some laying-off workers, while some still are reducing the pay packet of their workers. However calamitous this scourge looks, it may have some advantages to business. This is why Allinson, (2020) stated that every challenge brings immense joy and opportunities. Du-Plessi (2020) opined that the ravaging of the Black Death to Europe between 1347 and 1353 brought about reconstruction and renewal of European society. This set the pace for renaissance. Supporting Du-Plessi, Dorsey (2020) opined that during Covid-19 pandemic, governments set aside their differences to have a political will and foresight to build a united world good for all that will be equitable politically, economically and socially. Davies (2020) opined that technology industry is taking the advantage of COVID-19 to excel in cloud computing, electronic payments, and ecommerce, among others. This also in consonance with Ministry of Social Development New Zealand (2020) which provides wage subsidy and support to business during COVID-19, and save workers from being laid off. Olubiyi (2020) explained that the use of technology in the areas of distribution, sales, after-sales service, and inventory management will help rescue business dormancy during Covid-19. This will make market to be extended across borders with the introduction of e-Commerce, shopping, bargaining, and transactions can be done anywhere which makes businesses accessible everywhere. E-commerce platform will give business owners the clear vision and the precautionary measures required during pandemic. During Covid-19 Pandemic, shopping cost, transaction and operational costs are drastically reduced. This can also enhance business to continue despite restriction orders. It is a 24-hour trading without physical contacts. Olubiyi concluded that during Covid-19 pandemic, business revenues and sales improved market reach, access to new markets and cost savings in marketing and communication expenditure are greatly enhanced. Russia Statista Research Department (2020) stressed coronavirus (COVID-19) outbreak has helped their company to produce desired result, as well as making their workers to be ready to work for less pay up to 20 percent. Russia Statista Research Department further stated that Covid-19 has helped companies to take proactive decision in increasing its effectiveness, adoption of new technology, cutting costs, taking unpopular decisions, and having new opportunities. 
European Journal of Business and Innovation Research

Vol.9, No.2, pp. 12-26, 2021

Print ISSN: 2053-4019(Print),

Online ISSN: 2053-4027(Online)

\section{Research Gap and Contribution of Study}

A number research has been carried out in many parts of the world on Covid-19 pandemic. It appears that little research has been conducted in Nigeria. None conducted in Nigeria dealt on variables looked at in this study. (Profit margin, sales volume, cash flow, and possible advantages). This present study intends to fill the obvious gap. The findings of the study may be of help to business owners whose businesses are already collapsing in this Covid-19 pandemic period.

\section{Research Objectives}

The study was to assess the impact of COVID-19 on business. The specific purposes established the extent COVID-19 impacts:

1. Profit margin of business

2. Sales volume of business.

3. Cash flow of business

4. The possible advantages of COVID-19 on business

\section{Research Design}

A descriptive survey was employed. One thousand one hundred and seventeen (1117) known business owners in Edo State constituted the population. Proportionate sampling technique was used for the study. A sample of one hundred (235) respondents who are business owners formed the sample which is $21 \%$ of the population. Data was collected with the aid of a questionnaire made of two parts. Part ' $A$ ' is respondents' bio-data; while ' $B$ ' had 41 item statements measuring the various constructs identified in the research questions. The instrument was administered on a sample of 30 respondents distinct from those of the original study. A Cronbach alpha form of reliability was carried out and a reliability coefficient of 0.79 was obtained. The researcher engaged the services of six research assistants in administrating the questionnaires to business owners. Two weeks was used to collate and analyze the data. The value of 2.50 was the mean criterion. Therefore, a calculated value greater than 2.50 was high extent while below 2.50 was low extent.

\section{RESULTS}

Purpose One: Impact of COVID-19 on Profit of Business Table 1: Impact of COVID-19 on Profit of Business

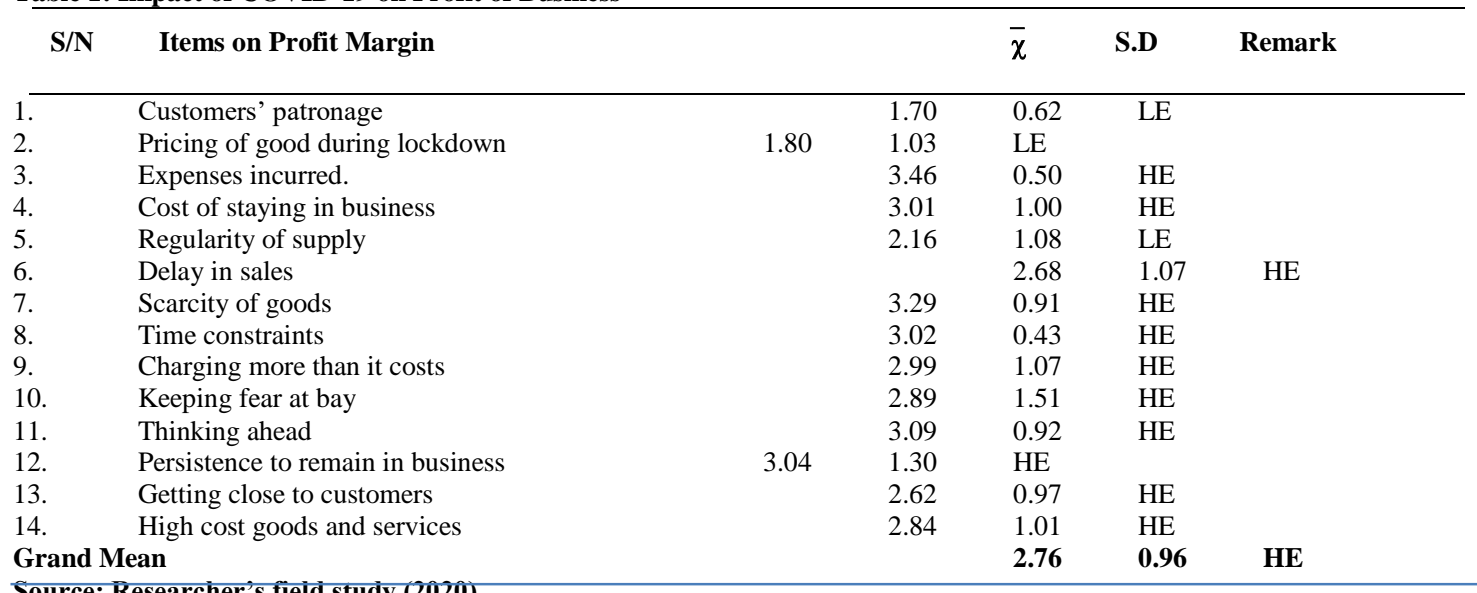


European Journal of Business and Innovation Research

Vol.9, No.2, pp. 12-26, 2021

Print ISSN: 2053-4019(Print),

Online ISSN: 2053-4027(Online)

All the items were rated high extent except items 1,2, and 5 that were rated low extent. The grand mean of 2.76 indicated that all the variables were rated high extent. The result shows that profit margin is maximized during COVID-19 pandemic.

Purpose Two: Impact of COVID-19 on Sales Volume

Table 2: Impact of COVID-19 on Sales Volume

\begin{tabular}{|c|c|c|c|c|c|}
\hline $\mathbf{S} / \mathbf{N}$ & Items on Sales Volume & & $\bar{\chi}$ & S.D & Remark \\
\hline $1 \overline{5 .}$ & Quantity of goods sold & 1.87 & 1.14 & LE & \\
\hline 16. & Often cash is collected from customers & 2.84 & 1.02 & $\mathrm{HE}$ & \\
\hline 19. & How fast sales are made & 1.70 & 0.63 & LE & \\
\hline 20. & Total sales in a day & & 1.80 & 1.04 & LE \\
\hline 21. & Gross revenue a day & & 1.54 & 0.51 & LE \\
\hline 22. & Number of times a stock is sold and replenished & 2.22 & 1.11 & LE & \\
\hline 23. & Number of share sold in stock market & 1.99 & 1.01 & LE & \\
\hline 24. & Focusing on improving sales velocity & & 2.70 & 1.06 & $\mathrm{HE}$ \\
\hline \multicolumn{3}{|c|}{ Grand Mean } & 2.08 & 0.94 & LE \\
\hline
\end{tabular}

All the items were rated low extent except items 16, and 24 that were rated high extent. The grand mean of 2.08 indicated low extent shows that sales volume is very low during COVID-19 pandemic

Purpose Three: Impact of COVID-19 on Cash Flow

Table 3: Impact of COVID-19 on Cash Flow

\begin{tabular}{llllll}
\hline S/N & Items on Cash flow & & $\bar{\chi}$ & S.D & Remark \\
\hline 25. & Paying of house rent & & 1.70 & 0.63 & LE \\
26. & Feeding of household & 1.80 & 1.03 & LE \\
27. & Meeting health challenges & 2.07 & 0.95 & LE & \\
28. & Paying for utilities & 2.42 & 0.54 & LE \\
$29 . \quad$ Savings for future endeavours & 2.38 & 1.88 & LE & \\
30. $\quad$ Buying of essential needs & 2.22 & 1.11 & LE & \\
31. $\quad$ Effecting repairs to house hold items & & 2.25 & 0.93 & LE \\
32. $\quad$ Paying interest on loans & 2.21 & 0.75 & LE & \\
33. $\quad$ Buying in bulk & 1.99 & 1.01 & LE & \\
Grand Mean & & $\mathbf{2 . 1 2}$ & $\mathbf{0 . 9 8}$ & LE \\
\hline
\end{tabular}

Source: Researcher's field study (2020)

All the items were rated low extent with a grand mean of 2.12 indicated that cash flow is low during CVID-19 pandemic. 
European Journal of Business and Innovation Research

Vol.9, No.2, pp. 12-26, 2021

Print ISSN: 2053-4019(Print),

Online ISSN: 2053-4027(Online)

Purpose Four: Advantages of COVID-19 on Business

Table 4: Advantages of COVID-19 on Business

\begin{tabular}{|c|c|c|c|c|c|}
\hline $\mathbf{S} / \mathbf{N}$ & Items on Advantages & & $\bar{\chi}$ & S.D & Remark \\
\hline $3 \overline{4}$. & Cloud computing & 2.89 & 0.90 & $\mathrm{HE}$ & \\
\hline 35. & Video conferencing & & 2.85 & 1.13 & $\mathrm{HE}$ \\
\hline 36. & Electronic payments & & 3.46 & 0.51 & $\mathrm{HE}$ \\
\hline 37. & E-commerce platform & & 3.00 & 0.71 & $\mathrm{HE}$ \\
\hline 38. & Accessibility to E-learning & 3.11 & 0.53 & $\mathrm{HE}$ & \\
\hline 39. & Online purchase delivery & 2.62 & 1.07 & $\mathrm{HE}$ & \\
\hline 40. & Streaming, gaming and video content platforms & 3.03 & 0.73 & $\mathrm{HE}$ & \\
\hline 41. & Telecommunication industry & & 2.84 & 0.99 & $\mathrm{HE}$ \\
\hline \multicolumn{2}{|c|}{ Grand Mean } & 2.98 & 0.82 & HE & \\
\hline
\end{tabular}

Source: Researcher's field study (2020)

All the items were rated high extent with a grand mean of 2.98 indicated that business organizations have a lot of advantages during COVID-19 pandemic.

\section{RESULTS AND DISCUSSION}

The finding of research question one shows that profit margin is maximized during COVID-19 pandemic. The result is in consonance with Ludwig (2020) who maintained that companies that do cleaning services and sanitize offices, restaurants and homes are doing very well during this Covid-19 pandemic. The researcher also opined that food delivery services are also in high demand. The finding is also in agreement with Goldstein (2020) who stated that big companies are using their reserves to give out loans to companies on high interest rate thereby increasing their profit margin. The finding is in contrast with the finding of LaPointe (2020) who maintained that there is a drop in profit generated by hospital compared to previous periods before Covid-19. The finding is in consonance with Egba (2020) who reported that MTN Nigeria recorded a significant increase in its revenue from 282.1 billion Naira to 329.1 billion Naira in the first quarter of 2020. Egba also maintained that MTN Telecommunication Company has made a steady growth during the pandemic period owing to the enforced lockdown. Egba further stated that the company made a profit $\$ 51.1$ billion in the first quarter of 2020 compared to 448.4 billion in the first quarter of 2019. The finding is in disagreement with Egba (2020) who concluded that MTNN's share price tumbled to as low as N90 in March 2020. The finding is in agreement with Switzerland (2020) which reported that E-commerce sales reached $29.4 \%$ which exceeded $10 \%$ of total Group sales before Covid-19. The finding is in contrast to Kim (2020) reported that the Consumer Electronics Division recorded lower earnings as a result of COVID-19 compared to a year before as well as decline in sale from TV business. The finding is in agreement with Coonrod (2020) who stressed that distiller of Missouri Ridge Distillery maximized an increase of profit in the production of hand sanitizer during covid-19 pandemic. The finding is in disagreement with Kilpatrick, Dess, and Barter (2020) who stated that tourism, hospitality, entertainment and air transportation had felt the negative impact of Covid-19. The finding is in support of Singh (2020) who reported that Puma's sales declined in the first quarter of 2020 due to impact of Corona virus that is ravaging the global market. 
European Journal of Business and Innovation Research

Vol.9, No.2, pp. 12-26, 2021

Print ISSN: 2053-4019(Print),

Online ISSN: 2053-4027(Online)

The finding of research question two shows that sales volume is very low during COVID-19 pandemic. This finding is in consonance with White (2020) who opined that the Coca-Cola company sale volume dropped during COVID-19. The finding is also in agreement with Bodnar (2019) who opined that sales dropped considerably during COVID-19 period. The finding is agreement with White (2020) who reported that Coca-Cola company global sales volumes fell by $25 \%$ in the first quarter of 2020. White further stated that the company experienced a short fall in its sales $\$ 8.6$ billion, representing a fall of $1 \%$ compared to the same period a year before. This is in contrast to Influencer Marketing Hub (2020) that maintained that YouTube videos watchers in Italy increased 20 times growth considerably compared to same period in 2019. This finding is in consonance with Aman (2020) who stated that the auto sector has been badly affected by Covid19 resulting from the sales of vehicle dropping to 683,000 units. Aman further stated that the sales of vehicles dropped to 197,000 units compared to 328,000 units in 2019. The finding of Shaulova (2020) in disagreement with the finding which revealed that during the coronavirus in Italy, the sales of over-the-counter in healthcare items increased significantly. Sales volume of pharmaceutical products grew by 30 percent compared to the same period of the previous year. The finding is also in agreement Meyer (2020) who stated that sales volume of apparel dropped to as low as $20 \%$.

The finding of research question three shows that cash flow is very low during COVID-19. This is in consonance with Tulder (2020) who opined that businesses cash flow is significantly impeded and discount rates higher during COVID-19 era. The researcher also opined that COVID-19 has brought liquidity issues to businesses thereby making companies to be distressed financially. The finding is also in consonance with Finkel (2020), who emphasized that during COVID-19 business expenses appear too high in relation to volume of sales which invariably affects cash flow. The finding is in consonance with ACCA Canada (2020) which reported that Covid-19 has negatively affected employee productivity by $52 \%$, launch of new products or services by $27 \%$ and cash flow stood at $23 \%$. The finding is also in agreement with Foss (2020) who stated that as a result of the coronavirus, business owners are experiencing tight cash flow to run various arms of their business. The finding is also in agreement with Foss, Shah (2020) who maintained that the major problem confronting business in this Covid-19 pandemic is the issue of cash flow which has been a hindrance to many organizations.

The finding of research question four indicates that business organizations have a lot of advantages during COVID-19 pandemic. This finding is in agreement with Davies (2020) who opined that technology industry is taking the advantage of COVID-19 to excel in cloud computing, electronic payments, and ecommerce, among others. This is also in consonance with Ministry of Social Development New Zealand (2020) which provides wage subsidy and support to business during COVID-19, and save workers from being laid off. Covid-19 has dealt a big blow to organization. Some have completely shut down, some doing skeletal services, some laying off workers, while some still are reducing the pay packet of their workers. The finding is in agreement with Allinson (2020) who stated that every challenge brings immense joy and opportunities. The finding agrees with Du-Plessi (2020) who opined that the ravaging of the Black Death to Europe between 1347 and 1353 brought about reconstruction and renewal of European society to set the pace for renaissance. The finding is in consonance with Dorsey (2020) who opined that during pandemic, 
governments set aside their differences to have a political will and foresight to build a world good for all that will be equitable politically, economically and socially. The finding is in consonance with Olubiyi (2020) who explained that the use of technology in the areas of distribution, sales, after-sales service, and inventory management will help rescue business dormancy during Covid19. This will allow market to be extended across borders with the introduction of E-commerce, shopping, bargaining, and transactions anywhere which makes businesses accessible everywhere. E-commerce platform will give business owners the clear vision and the precautionary measures required during pandemic. During Covid-19 pandemic, shopping cost, transaction and operational costs, are drastically reduced. This can also enhance business to continue despite restriction orders. It is a 24-hour trading without physical contacts. Olubiyi concluded that during pandemic, business revenues and sales, improve market reach, access to new markets and cost savings in marketing and communication expenditure will greatly be enhanced. The finding agrees with Russia Statista Research Department (2020) which stressed that coronavirus (COVID-19) outbreak has helped their company to produce desired result, as well as making their workers to be ready to work for less pay up to 20 percent. Russia Statista Research Department further stated that Covid-19 has helped companies to take proactive decision in increasing its effectiveness, adoption of new technology, cutting costs, taking unpopular decisions, and having new opportunities.

\section{CONCLUSION}

It was concluded that COVID-19 impacts the profit to high extent, sales volume to low extent, cash flow of business to low extent. The study further concluded that a lot of advantages are derived during COVID-19 pandemic. The study recommended that business owners should engage in market timing to enable customers to know their time of opening for business for those who are given the opportunity to open. Business owners should engage more in online sales to increase sales volume. Business owners should engage in massive savings before crises to avoid cash crunch during economic crises, and schools should be prepared for e-learning to avoid total lock down.

\section{Limitations of the Study}

One State in Nigeria was used for this study in a country of 36 States. Hence, more samples might generate different findings. The findings might not be used for entire Nigeria. This is an obvious limitation. Respondents were unwilling to respond to questionnaires on time. This actually delayed the collation of results.

\section{Contribution to Knowledge}

The study has empirically established that Covid-19 may not be able to shutdown business completely if adequate steps are taken to salvage the situation.

\section{Suggestions for Further Studies}

Corona Virus (Covid-19): A calamitous threat to business in Nigeria. 
European Journal of Business and Innovation Research

Vol.9, No.2, pp. 12-26, 2021

Print ISSN: 2053-4019(Print),

Online ISSN: 2053-4027(Online)

\section{References}

Abioye, O. (2020). Next generation - The impact of COVID-19 on the future of food systems in Africa. Retrieved from https://www.thechicagocouncil.org/blog/globalfood-thought/next-generation-impact-covid-19

ACCA Canada (2020). Covid-19: Employee productivity, cash flow, new products and services all impacted by the effects of the pandemic, finds new research. Retrieved from https://www.globenewswire.com/newsrelease/2020/04/16/2017262/0/en/Covid-19-Employee-productivity-cash-flow-newproducts-and-services-all-impacted-by-the-effects-of-the-pandemic-finds-newresearch.html

Accounting Tools (2020). Sales volume. Retrieved from https://www.accountingtools.com Akanni, L.O. (2020). The implication of Covid-19 pandemic on the Nigerian economy. Retrieved from http://cseaafrica.org/the-implication-of-covid19-on-thenigerian-economy/

Allison, A.K. (2020). Fighting COVID-19 is my contribution to my country. Retrieved from https://www.un.org/africarenewal/web-features/coronavirus/healthcare/fighting-covid-19my-contribution-my-country

Aman, M. (2020). Weekly update: COVID-19 impact on global automotive industry. Retrieved from https://www.counterpointresearch.com/weekly-updates-covid-19impact-global-automotive-industry/

Bianco, C. (2020). Infected: The impact of the coronavirus on the Middle East and North Africa. European Council on Foreign Relations. Retrieved from https://www.ecfr.eu/commentary-infected-the-impact-of-the-corona-virus-on-the-middle-

Bodnar, K. (2019). Deal volume and sales response rates drop to new lows COVID-19 benchmark data, updated weekly]. Retrieved from https://blog.hubspot.com/marketing/covid-19-benchmark-data-edition2

Chilufa, C. (2020). The African economy is "infected": The economic impact of COVID-19 is worsening poverty in Africa. Retrieved from https://xavier.network/news/the-african-economy-is-infected-the-economic-impact-ofcovid-19-is-worsening-poverty-in-africa/

Coonrod, M. (2020). COVID-19 Coverage: Slim profit margin still helps. Retrieved from https://sbj.net/stories/covid-19-coverage-slim-profit-margin-still-helps, 68949

Corporate Finance Institute (2020). Cash flow. Retrieved from https://corporatefinanceinstitute.com/resources/knowledge/finance/cash-flow/

Davies, B. (2020). What is a Business? - Definition, characteristics \& examples. Retrieved on from https://study.com/academy/lesson/what-is-a-business-definitioncharacteristics-examples.html

Dorsey, J.M. (2020). Refugees and Shantytowns in MENA and beyond imperil global public health commentary No. 598. Middle East Institute. Retrieved from https://www.mei.org.in/commentary-598.

Du Plessis, Q. (2020). An unprecedented crisis: The economic ramifications of Covid-19. Mail and Guardian. Retrieved from https://www.mg.co.za/article/2020-0404-an-unprecedented-crisis-the-economic-ramifications-of-covid-19

Egba, L. (2020). Analysis: MTN's blow out Q1 profit vs Covid-19 headwinds. Retrieved 
European Journal of Business and Innovation Research

Vol.9, No.2, pp. 12-26, 2021

Print ISSN: 2053-4019(Print),

Online ISSN: 2053-4027(Online)

from https://nairametrics.com/2020/05/12/analysis-mtns-blow-out-q1-profit-

vs-covid-19-headwinds/

European Centre for Diseases Prevention and Control (2020). Coronavirus disease. Retrieved from https://www.ecdc.europa.eu/en

Finkel, D. (2020). The 4 most common causes of cash flow challenges (and what to do about them). Retrieved from https://www.inc.com/david-finkel/the-4-mostcommon-causes-of-cash-flow-challenges-and-what-to-do-about-them.html

Foss, K. (2020). How will COVID-19 impact your cash flow? Retrieved on $2^{\text {nd }}$ June 2020 from https://www.bradymartz.com/news/how-will-covid-19-impact-your-cash-flow/

Goldstein, M. (2020). Some big investors smell profit in virus-plagued companies. Retrieved from https://www.nytimes.com/2020/04/03/business/private-equityhedge-funds-coronavirus.html

Harding, A. (2020). The 12 dealiest viruses on earth. Retrieved from https://www.livescience.com/56598

Hayes, A. (2019). What is business? Retrieved from https://www.investopedia.com/terms/b/business.asp

Ibekwe, N. (2020). COVID-19: Arik cuts salaries by $80 \%$, places $90 \%$ of staff on leave without pay. Retrieved from https://www.premiumtimesng.com/business/business-news/389578

Influencer Marketing Hub (2020). Covid-19 marketing reports: Statistics and Ad spend. Retrieved from https://influencermarketinghub.com/coronavirusmarketing-ad-spend-report/

Johnson, R. (2019). What are the benefits of making profits? Retrieved from https://smallbusiness.chron.com/benefits-making-profit.

Kilpatrick, J., Dess, J. \& Barter, L. (2020). Managing cash flow during a period of crisis. Retrieved from https://www2.deloitte.com/content/dam/Deloitte/global/Documents/About-Deloitte/gxCOVID-19-managing

Kim, K.N. (2020). Samsung Electronics announces first quarter 2020 results. Retrieved from https://news.samsung.com/global/samsung-electronics-announces-firstquarter-2020-results

Kokemuller, N. (2020). Advantages and disadvantages of sales volume-based quota system. Retrieved from https://smallbusiness.chron.com/advantagesdisadvantages-sales-volume-based-quota-system

LaPointe, J. (2020). Hospital revenues rose, margins fell before COVID-19 outbreak. Retrieved from https://revcycleintelligence.com/news/hospital-revenues-rosemargins-fell-before-covid-19-outbreak

Ludwig, S. (2020). 15 small businesses thriving during coronavirus. Retrieved from https://www.uschamber.com/co/start/strategy/coronavirus-successful-businesses

Meyer, S. (2020). Understanding the COVID-19 effect on online shopping behavior. Retrieved from https://www.bigcommerce.com/blog/covid-19ecommerce/\#understanding-panic-buying-and-coronavirus

Ministry of Social Development New Zealand (2020) COVID-19 support for employers. Retrieved from https://workandincome.govt.nz/covid-19/support-foremployers.html 
European Journal of Business and Innovation Research

Vol.9, No.2, pp. 12-26, 2021

Print ISSN: 2053-4019(Print),

Online ISSN: 2053-4027(Online)

$\mathrm{Ng}$, A. (2020). Three ways the corona virus could have an impact on Middle East economies.

Retrieved from https://www.cnbc.com/2020/03/12/three-ways-the-

corona-virus-could-impact-the-middle-east-economies.html.

Olubiyi, T. (2020). COVID-19: Hidden advantage for SMEs. Retrieved from https://businessday.ng/opinion/article/covid-19-hidden-advantage-for-smes/

Onyekwena, C. \& Ekeruche, M.A. (2020). Understanding the impact of the COVID-19 outbreak on the Nigerian economy. Retrieved from

https://www.brookings.edu/blog/africa-in-focus/2020/04/08/understanding-the-impact-ofthe-covid-19

Ozili, P.K. \& Arun, T.G. (2020). Spillover of COVID-19: impact on the global economy. Working paper. Retrieved from

file://C:/Users/USER/AppData/Local/Temp/covid19nigeriacoronavirus.pdf

Riboua, Z. (2020). Coronavirus experiences on the ground in the Middle East. Atlantic Council. Retrieved from

https://www.atlanticcouncil.org/blogs/menasources/coronavirus-experiences-on-theground-in-the-middle-east.

Russia Statista Research Department (2020). Are there positive changes for business in general over the period of the coronavirus epidemic? Retrieved from https://www.statista.com/statistics/1108918/russia-covid-19-advantages-for-business/

Seen, C.M. (2020). Impact of COVID-19 on transfer pricing arrangements. Retrieved from https://home.kpmg/my/en/home/insights/2020/03/the-business-implications-ofcoronavirus/impact

Shah, H. (2020). How CFOs can minimize the impact of Covid-19 and build business resilience in times of disruption. Retrieved from https://economictimes.indiatimes.com/small-biz/money/how-cfos-can-minimise-theimpact-of-covid-19-and-build-business-resilience-in-times-ofdisruption/articleshow/75217039.cms

Shaulova, E. (2020). Impact of COVID-19 on OTC healthcare sales in Italy 2020. Retrieved from https://www.statista.com/statistics/1110867/impact-of-covid-19-onotc-healthcare-sales-in-italy/

Shereen, M.A., Khan, S., Kazmi, A., Bashir, N., \& Siddique, R. (2020). COVID-19 infection:

Origin, transmission, and characteristics of human coronaviruses. Journal of Advanced Research, 24, 91-98

Singh, M. (2020). Xiaomi reports Q4 revenue jump, beats estimates. Retrieved from https://techcrunch.com/2020/03/31/xiaomi-q4-annual-2019/

Switzerland, V. (2020). Nestlé reports three-month sales for 2020, provides COVID-19 update. Retrieved from https://www.nestle.com/media/pressreleases/allpressreleases/three-month-sales-2020

Tregurtha, K. (2020). 5 ways to solve small business cash flow problems during COVID-19. Retrieved from https://www.ondeck.com/resources/5-ways-to-maximizecash-flow-during-the-covid-19-outbreak

Tulder, K.N. (2020). Covid-19: Valuation challenges and opportunities. Retrieved from http://www.taeconomics.com/covid-19-valuation-challenges-and-opportunities

White, M. (2020). Coca-Cola sales volume declines 25\% in April due to Covid-19 impact. 
European Journal of Business and Innovation Research

Vol.9, No.2, pp. 12-26, 2021

Print ISSN: 2053-4019(Print), Online ISSN: 2053-4027(Online)

Retrieved from https://www.foodbev.com/news/coca-cola-salesvolume-declines-25-in-april-due-to-covid-19

York, M. (2019). 6 ways to increase profits for your small business. Retrieved from https://www.the balancesmb.com/steps-to-increase-small-business-profits

\section{Author's Profile}

Robinson Owenvbiugie is an academic of the University of Benin, Faculty of Education, Department of Business Education, a Senior Lecturer. He holds a PhD in Business Education. He has more than 40 publications to his credit. He is married with children. 